\title{
The United Kingdom's First Woman Law Professor: An Archerian Analysis
}

\author{
FIONA COWNIE*
}

In 1970, at Queen's University Belfast, Claire Palley became the first woman to hold a Chair in Law at a United Kingdom university. However, little is known about the circumstances surrounding this event, or Claire Palley herself. This article (part of an extended project exploring her life history) seeks to address the question 'Was there something about Claire Palley herself that made it more likely she would become the United Kingdom's first female law professor?' Initially focusing on method, it seeks to answer that question by utilizing, for the first time in the context of legal education, the theoretical perspective provided by the work of the sociologist Margaret Archer. Reflecting upon Claire Palley's subjectivity, it focuses on those aspects of her personality which enabled her to pursue a successful career and become a pioneer in her chosen profession.

\section{INTRODUCTION}

Both at the time of her appointment and since, almost nothing has been said publicly about Professor Palley's pioneering role. At the time, there was no mention of her appointment in the Times, despite the fact that the paper took its role as a journal of record seriously then, and included a section on 'University News'. It was not until the appointment of Gillian White at Manchester in 1975 (the second woman to become a Law Professor in the United Kingdom) that Claire Palley's appointment was mentioned in the Times. Professor C.F. Parker, then President of the Society of Public

\section{* School of Law, Keele University, Staffordshire ST5 5BG, England f.cownie@keele.ac.uk}

I would like to thank Claire Palley for participating in this research and for generously agreeing to share her life story. I would also like to thank Linda Mulcahy, David Sugarman, and Tony Bradney for their helpful comments on an earlier draft of this article. Any errors remain the responsibility of the author. 
Teachers of Law (SPTL) wrote to the paper to point out that a statement released by Manchester University, talking about Gillian White as the first English woman to be appointed to a Chair in Law in the United Kingdom, was very carefully worded. He noted that Claire Palley (who had been born in South Africa) and Frances Moran (Professor of Law at Trinity College Dublin 1944-63) had both held chairs in Law before Gillian White. ${ }^{1}$ (Professor Parker's reference to Frances Moran, the very distinguished holder of the Regius Chair in Law at Trinity College, is rather confusing, as she did not hold a United Kingdom Chair). This discussion of Claire's appointment came not only several years after the event, but was also somewhat opaque. Similarly, when the history of Queen's University Belfast was published in 1994 no mention was made of Claire's achievement. ${ }^{2}$ Thus the public record of the appointment of the first woman to hold a Chair in Law in the United Kingdom is extremely scant.

One of the most frequent questions I am asked about the appointment of Claire Palley is 'Why her?' 'What was it about her that made it likely she would be the first woman to occupy a Chair in Law in a United Kingdom university?' These questions, of course, are mainly focused on only half the story, what social scientists call 'agency', based on the characteristics of the individual involved. In the main, this article focuses on providing an answer to that question by analysing Claire Palley's subjectivity. But in thinking about an individual's subjectivity, we also have to take account of 'structure', which includes forces in society such as criteria for appointment and promotion. ${ }^{3}$ And in thinking about structure, we also need to take account of 'culture', the attitudes, behaviours, and ways of doing things which reflect a shared understanding of the way the world works. As this project progresses, it is intended to take a holistic approach to Claire Palley's life, placing it in its social, economic, and political contexts. At this initial stage, however, the focus is firmly on Claire's subjectivity.

It is here that the theory put forward by Margaret Archer is particularly useful. Archer is a proponent of realist social theory, which sees structure and agency as 'distinct strata of reality, as the bearers of quite different properties and powers', and her work is often referred to as being that of a 'critical realist'. ${ }^{4}$ Technically, talking about a critical-realist approach to the study of social life is incorrect, because critical realism is ' ... a philosophical approach that seeks to be an ontological "under-labourer" for a range of

1 C.F. Parker 'Women Law Professors' Times, 28 June 1975, 13. Claire Palley remembers that she did not point out to Professor Parker that she was English by descent and a citizen of the United Kingdom at birth!

2 B.M. Walker and A. McCreary, Degrees of Excellence: The Story of Queen's, Belfast $1845-1995$ (1995).

3 K. Knorr-Cetina and A.V. Cicourel (eds.), Advances in Social Theory and Methodology (1981).

4 M.S. Archer, Structure, Agency and the Internal Conversation (2003) 2. 
substantive theories in the natural and social sciences. ' 5 'Critical realism' is therefore used here as a convenient way of referring to theories, such as Archer's, which share a basic commitment to critical-realist tenets.

In Structure, Agency and the Internal Conversation, the most recent of a quartet of books which Archer has written exploring aspects of this topic, she analyses the ways in which structures influence agents, and vice versa. ${ }^{6}$ Her basic point is that agents/actors have self-consciousness and structures do not, and her focus is on the mediating process between the two. To deal adequately with the interplay between structure and agency, we must specify how structural and cultural powers impinge upon agents, and how agents use their own personal powers to act 'so rather than otherwise'. 7 Structural properties impinge upon agents so as to condition their actions; this process involves both constraints and enablements, and they shape the situations in which we find ourselves, such that some courses of action are impeded and others facilitated. ${ }^{8}$ The fundamental question is "How do agents interact with structural constraints and enablements?" Archer argues that they do it through the 'internal conversation', which can be broadly understood as our innermost thoughts. In this article, I seek to show how the particular kind of 'internal conversation' in which Claire Palley engaged made her the sort of person who might be appointed to a pioneering role in a university law school.

\section{LEGAL BIOGRAPHIES AND WRITING WOMEN'S HISTORY}

The fact that we know so little about the appointment of Claire Palley to her Chair in Law is unsurprising. In the legal sphere, as with other professions, when biographies have been written, they have tended to be those of men. This is true of the numerous biographies of judges, and in general of the biographies of famous (and not so famous) legal practitioners. In a legal context it is evident that even when biographies of women have been written, they have generally concentrated on female legal practitioners or judges, rather than academics. Recent examples include Mary Jane Mossman's excellent comparative study of the first women to become legal practitioners in jurisdictions ranging from India to North America, and Hilary Heilbron's

5 A. Mutch, 'Constraints on the Internal Conversation: Margaret Archer and the Structural Shaping of Thought' (2004) 34 J. for the Theory of Social Behaviour 429, at 429. For a discussion of critical realism, see A.Sayer, Method in Social Science: A Realist Approach (1992); A. Sayer, Realism and Social Science (2000).

6 The other three books Archer has written on the relationship between structure and agency are: M.S. Archer, Realist social theory: the morphogenetic approach (1995); M.S. Archer, Culture and agency: The place of culture in social theory (1996); M.S. Archer, Being Human: The Problem of Agency (2000).

7 Archer, op. cit., n. 4, p. 3.

8 id., p. 4. 
biography of her mother, Rose Heilbron, the first female judge in England. ${ }^{9}$ Even when biographies of legal academics are written, they also tend to be about men, such as R. Gwynedd Parry's biography of Sir David Hughes Parry QC and Nicola Lacey's biography of Herbert Hart. ${ }^{10}$ Of course, this is partly a reflection of the general position of women in society, and of the fact that women were denied leading roles in these spheres. Nevertheless, the result is that our knowledge of the (professional) lives of women legal academics and their contribution to the development of the discipline of law is particularly scant. Consequently, throwing light on the life of the United Kingdom's first woman law professor enables us to reconsider what personal qualities might assist women wishing to gain success in the (legal) academy. As Rosemary Auchmuty said of her biographical subject, Miss Bebb (of $B e b b$ v. The Law Society fame), ‘... to the student of women's legal history she is important, because she was part of a struggle for equality that is still ongoing.' ${ }^{11}$ That is equally true of the life of Claire Palley.

\section{BIOGRAPHICAL METHOD}

In considering the use of biography as a research tool, it is useful to bear in mind the distinction between 'life story' and 'life history'. As Goodson argues, 'life story' is the story we tell about our life. 'Life history' is a collaborative venture between the subject of biography and the researcher, which draws on a wide range of evidence so as to locate the life in a broader contextual analysis. ${ }^{12}$ The life history is the life story located within its social, political, and historical context. In order to obtain the life story upon which this life history is based, I interviewed Claire Palley, in her own home, over a period of four days in November 2013. All the interviews were recorded and transcribed, and a document produced, which tells Claire's life story. Each interview lasted about two hours, some days for longer. In addition, notes were taken (with Claire's permission) of informal conversations during those four days, and these notes provided additional information which was incorporated into the life-story document (which ran to some 20,000 words). All Claire's words in this article are taken from that source (on file with the author) unless stated otherwise. The interviews were strongly informed by ethnographic method, viewed as 'social events in which the interviewer (and for that matter the interviewee) is a participant

9 M.J. Mossman, The First Women Lawyers (2006); H. Heilbron, Rose Heilbron: The Story of England's First Woman Queen's Counsel and Judge (2012).

10 R.G. Parry, David Hughes Parry - a jurist in society (2010); N. Lacey, A Life of H.L.A. Hart: The Nightmare and the Noble Dream (2006).

11 R. Auchmuty, 'Whatever happened to Miss Bebb? Bebb v The Law Society and women's legal history' (2010) 31 Legal Studies 199, at 199.

12 I. Goodson (ed.), Studying Teachers' Lives (1992) 6. 
observer.' ${ }^{13}$ Claire also provided copies of various documents, including CVs, articles, and speeches. The final life-story document was checked by Claire for factual accuracy; she made no changes to the analysis, although she commented upon it, and some of those comments are included in this article.

Clearly, the production of the life story on which this life history is based was a collaborative venture. It was also influenced by my previous experience of using an ethnographically informed approach to interviewing. ${ }^{14}$ As a researcher, I drew up an interview schedule of topics I thought might ensure that we explored all aspects of Claire's life, but as we talked, I also gathered information about aspects of Claire's life which she introduced to the conversation. ${ }^{15}$ The life story thus emerged as the consequence of a series of what Burgess would term 'conversations with a purpose'; Burgess describes '... a series of friendly exchanges in order to find out about peoples' lives.' 16

Discussion of obtaining data by having 'conversations' inevitably leads to a consideration of the location of the self in the research process. As Measor and Sikes comment:

The sociologist is in the action and a part of the context. Therefore there is an obligation on them to unpick, or at the very least document their own place in what happened. The sociologist is not a passive transcriber, nor a dispassionate observer.

Feminist writing on methodology, in particular, has for some time stressed the importance of reflexivity in research. ${ }^{18}$ In order to address these issues, I want to draw the reader's attention to the fact that like Claire Palley, I am a female law professor who has also undertaken substantial administrative roles in the institutions in which I have worked. During the preparations for this research I discovered that Claire and I shared a mutual friend (Professor William Twining, Emeritus Quain Professor of Jurisprudence at University College London) and she told me that she had consulted him before agreeing to participate in the research. Claire and I had never met before the interviews took place, but we met as academic colleagues and she invited me

13 M. Hammersley and P. Atkinson, Ethnography: Principles in Practice (2007, 3rd edn.) 120 .

14 See F. Cownie, Legal Academics: Culture and Identities (2004) 20.

15 I am particularly grateful to Dvora Liebermann, PhD student at the London School of Economics, for her invaluable suggestions about topics to include in my interviews with Claire Palley.

16 R. Burgess, In The Field (1984) 102, 105.

17 L. Measor and P. Sikes, 'Visiting Lives: Ethics and Methodology in Life History' in Goodson, op. cit., n. 12, p. 212.

18 See, for example, L. Stanley and S. Wise, Breaking out: Feminist consciousness and feminist research (1983); S. Roseneil, 'Greenham Revisited: Researching Myself and My Sisters' in Interpreting the Field: Accounts of Ethnography, eds. D. Hobbs and T. May (1993); B. Skeggs, 'Techniques for Telling the Reflexive Self' in Qualitative Research in Action, ed. T. May (1992). 
to stay with her in order to carry out the interviews. Whilst I was staying with her we discovered a mutual love of music and in between interviews listened to concerts on the television. Following Oakley's view that 'in research there should be no intimacy without reciprocity', I also shared aspects of my life with Claire - we talked about husbands and families, about teaching law and about food and music. ${ }^{19}$ As Hammersley and Atkinson comment, 'The value of pure sociability should not be underestimated as a means of building trust. ${ }^{20}$ The process of self-disclosure is an important aspect of life-history research, as it reinforces the trust between researcher and researched. Hammersley and Atkinson point out that, for the researcher, this tends to involve presentation of those aspects of one's self and life that provide a bridge for building relationships with participants and the suppression of those which constitute a possible barrier. ${ }^{21}$ Claire and I both adopted this approach, skirting round the subject of politics at first, until we had worked out where we were both 'coming from'. But, in general, Claire was very open about all aspects of her life; on just two occasions she said, 'We won't put this down, but I'll just tell you' when she thought that to say something publicly might hurt other people.

In drawing attention to these details of the research process, I am acknowledging my role as researcher in the construction of the life story, which was based around data elicited by establishing a relationship of trust which progressed as the research progressed, to the extent that it can be referred to as 'interactive' research. Clearly, this research could also be classed, in ethnographic terms, as 'insider research'. Insider research does not appear at all in Gold's classic categorization of field roles, and it is frequently not discussed in textbooks on methodology. ${ }^{22}$ Some writers see insider research as problematic: methods texts tend to stress the need to maintain a sense of distance. ${ }^{23}$ Frequently, alienation or distance has been seen as a positive analytical tool, and the consequent denial of self as an epistemological necessity. ${ }^{24}$ Conventionally one is cautioned that familiarity may be a problem; Roseneil has described the potential difficulty of being too close 'to see the sociological significance of that which appears to be completely normal, or to form criticisms. ${ }^{25}$ However, Coffey argues that drawing a simple dichotomy between involvement and over-immersion is unhelpful and crude. In her view, the self is very much part of the research

19 A. Oakley, 'Interviewing women: a contradiction in terms' in Doing Feminist Research, ed. H. Roberts (1981) 49.

20 Hammersley and Atkinson, op. cit., n. 13, p. 70.

21 id., p. 109.

22 R. Gold, 'Roles in Sociological Field Observations' (1958) 36 Social Forces 217.

23 See, for example, Hammersley and Atkinson, op. cit., n. 13; S. Delamont, Fieldwork in Educational Settings: Methods, Pitfalls and Perspectives (2002, 2nd edn.).

24 A. Coffey, The Ethnographic Self: Fieldwork and the representations of identity (1999) 21.

25 Roseneil, op. cit., n. 18, ch. 7. 
endeavour and researchers should not seek, by implication or otherwise, to deny that fact. ${ }^{26}$

Thus there is much debate among social scientists about the advantages and disadvantages of 'insider research'. Advantages include the researcher's understanding of the context in which the researched subject lived, the ability to speak a common language (including jargon and 'in-jokes'), and the likelihood of obtaining rich data from the research subject. I would certainly argue that, for this project, my position as an academic insider helped me to obtain some rich data. Equally, my previous experience of carrying out insider research over extended periods has given me experience of subjecting data gained in this way to academic critique. ${ }^{27}$ However, there is a risk that some detachment may have been sacrificed in order to obtain this quality of data. Nevertheless, I have striven to achieve what Bourdieu termed 'participant objectification', seeking to avoid the false choice between the unreal intimacy of a subjectivist position and the equally misleading superiority of objectivism. ${ }^{28}$

Oral history also plays an important part in a project such as this. As Nelson argues:

Numerous studies have shown that there is a gap between what we can discover when we rely on published accounts of some historical event and what we can discover when we ask questions of the on-site participants of those same events. ${ }^{29}$

However, oral history 'can lead us astray' because as a method it is notoriously bad for giving an overview or an accurate sequence of events. ${ }^{30}$ It is important, therefore, to understand that while at this initial stage in the project the life history is generally presented uncritically, as the project progresses the focus will broaden as will the critique. At present, however, the focus is on Claire's subjectivity, and the interest lies in using the theory of Margaret Archer to analyse the life story in an attempt to uncover what it was about Claire Palley herself that made her a likely candidate to become the United Kingdom's first female law professor.

26 id., p. 36.

27 I have previously carried out insider research among Quakers: A. Bradney and F.Cownie Living Without Law: An ethnography of Quaker decision-making, dispute avoidance and dispute resolution (2000), and also among contemporary legal academics: F. Cownie Legal Academics: Culture and Identities (2004).

28 R. Jenkins, Bourdieu (1992) 47.

29 M.K. Nelson, 'Using Oral Histories to Reconstruct the Experiences of Women Teachers in Vermont $1900-1950$ ' in Goodson, op. cit., n. 12, p. 168.

30 id., p. 185. 


\section{'THE INTERNAL CONVERSATION'}

Margaret Archer's notion of the internal conversation involves three interrelated arguments. First, that our subjectivity is our own internal property, that it is real, and that it is influential. It is a personal interior property, with a first-person subjective ontology and with powers that can be causally efficacious in relation to ourselves and society. Secondly, we live in a social world that has powers and properties which can constrain (and enable) our actions. Thirdly, that we are capable of reflexively monitoring ourselves in relation to our circumstances, whilst the structural forces are incapable of doing the same towards us. ${ }^{31}$

Archer rejects the behaviourist argument that there is no difference in kind between a person's knowledge about herself and her knowledge about other people; she argues that we have inner lives, knowable only by our firstperson selves. This she conceptualizes as 'the inner conversation'. ${ }^{32}$ This private life of the mind is not simply:

... a passive matter of 'looking inward' to see what we found there, but an active process, in which we continuously converse with ourselves, precisely in order to define what we do believe, do desire and do intend to do. ${ }^{33}$

Archer goes on to argue that the 'internal conversation' is a process by which:

... agents reflexively deliberate upon the social circumstances that they confront ... the ongoing 'internal conversation' will mediate agents' reception of these structural and cultural influences. In other words, our personal powers are exercised through reflexive interior dialogue and are causally accountable for the delineation of our concerns, the definition of our projects, the diagnosis of our circumstances and, ultimately, the determination of our practices in society. ${ }^{34}$

In considering the internal conversation, Archer argues that humans are reflexive beings, who deliberate about their circumstances, and thus decide on their personal courses of action in society. However, we do not all exercise our reflexivity in the same way. ${ }^{35}$ Through the empirical work she carried out in order to test her theory, she identifies humans as engaging in three kinds of internal conversation. "Communicative reflexives' initiate internal dialogues in their own minds, but seek to resolve issues by sharing their problems, discussing their decisions with others. ${ }^{37}$ 'Autonomous reflexives' engage in an internal dialogue with themselves; they neither need

31 Archer, op. cit., n. 4, p. 14.

32 id., p. 22.

33 id., p. 34.

34 id., p. 130.

35 id., p. 167.

36 id., part 11.

37 id., p. 167. 
nor wish to supplement this by external exchanges with other people. ${ }^{38}$ 'Meta-reflexives' are reflexive about their own reflexivity; it is easiest to understand this concept through an example. A person thinks:

I think $\mathrm{X}$ is pretty stupid; but they made a smart remark just now. Why do I think they're stupid? Because they're obese, and I'm prejudiced about fat people. I shouldn't be taken in by stereotypes.

This is an exercise in meta-reflexivity. Meta-reflexivity is something many people engage in occasionally, but Archer's 'meta-reflexives' engage in it frequently. ${ }^{39}$

It is because of the ability of Archer's theory to draw out, in a particularly clear way, the aspects of an individual's subjectivity which cause them to take certain decisions, and make it likely that they will have certain attitudes and hold to certain values, that it is particularly apposite as a means of identifying what it was about Claire Palley that made it unsurprising, in terms of her subjectivity, that she was the first female professor of law in the United Kingdom.

Archer's theoretical work is closely argued and persuasive and is wellregarded by her peers. ${ }^{40}$ Her ideas provide a clear framework for considering how structural/cultural properties shape situations for agents. They constitute constraints and enablements which are responded to by agents using their own personal powers. This is a process of reflexive mediation, whereby agents mediate the influence of structural factors upon the courses of action they pursue. This reflexivity is practised through the 'internal conversation'. In the analysis which follows, I seek to demonstrate how Archer's theoretical framework gives us insights into Claire Palley's 'internal conversation', and by so doing, provides us with some indications of the aspects of Claire Palley's subjectivity which assisted her in becoming the United Kingdom's first female professor of law.

\section{CLAIRE PALLEY AND AUTONOMOUS REFLEXIVITY}

In the empirical work which she published in Structure, Agency and the Internal Conversation, Margaret Archer identified objective features in the social background of her interviewees which were propitious for the development of the three particular iterations of reflexivity which she identified. For 'autonomous reflexives' it was an early 'contextual dis-

38 id., p. 210.

39 id., pp. 255-6.

40 See, for example, N. Wiley, 'Structure, Agency and the Internal Conversation by Margaret S. Archer: Review by Norbert Wiley'(2005) 110 Am. J. of Sociology 1528; A. Mutch, 'Constraints on the Internal Conversation: Margaret Archer and the Structural Shaping of Thought' (2004) 34 J. for the Theory of Social Behaviour 429. 
continuity' which deprived them of a durable group of interlocutors and thus threw them back upon their own internal mental resources for the purposes of deliberation. ${ }^{41}$ As we shall see, Claire Palley generally falls into Archer's category of 'autonomous reflexive'.

Born in South Africa in 1931, her circumstances contrived to provide that 'contextual discontinuity' that Archer speaks of:

My childhood was a little bit disrupted, really, because my parents separated (temporarily) when I was a small child, of about a year old, and I went to live with my grandparents. I sort of regarded my grandmother as my mother really, I suppose.

Her tendency to autonomy was developed by the fact that this was a house full of adults, which revolved around her grandfather, who was a judge. 'It was a very, sort of, quiet house ... [with a] huge library, I used to sit in the library and look at the books.' Some concessions were made for the small child, but mostly by Claire's grandmother:

I had a very close relationship with my grandmother, she was wonderful, I used to come to her bed at about seven o'clock in the morning and then she'd have a new fairy-tale book and she used to read to me in bed. And the tea was brought and then we'd have tea and Marie biscuits. And then at eight o'clock my grandfather would come from his bedroom with his newspaper and I had to disappear.

Claire's only sibling was a younger sister, nearly eight years younger; the age difference, especially when they were young, did not aid a close relationship, and when they were older, the two sisters disagreed politically for a long time, so did not grow close. ${ }^{42}$

The contextual discontinuity in Claire's life continued as she went to boarding school, and then on to university, where she initially read microbiology. Her reasons for doing so are revealing:

... I didn't want to go back home when I left school, so I decided I would do Microbiology; there was a book called The Microbe Hunters by a man called Paul de Krieff and he wanted to discover microbes, but the great thing about this was you could only do Microbiology at Capetown University, which was why I wanted to do Microbiology.

Capetown was far away from Claire's home in Durban. So by the age of 18, she had moved between her grandparents' home and her own, then spent time at boarding school and finally moved away to Capetown to study. Archer notes that it is a feature of autonomous reflexives that their social context lacks stability, so that before a person has become familiar with it,

41 Archer, op. cit., n. 4, p. 257.

42 Claire commented that her sister '... became an MP and was on the Constitutional Commission for the new Constitution in South Africa, and was very active, and on the Human Rights Committee, and has moved progressively Left. We get on better now she has moved to the Left.' 
they move on and are deposited in a new context. ${ }^{43}$ Thus autonomous reflexives gather no enduring network of early friends with whom they build a lasting relationship anchored in a common context; instead, they are thrown back on their own resources. Claire acknowledges that this is true of herself. Speaking of her friendship with William and Penelope Twining she commented 'But that's an exceptional friendship. I was very friendly too with Daphne Park until she died, but I've been quite a lonely person in my life'.

Claire's experience at university continued to reflect her tendency to autonomous reflexivity. Archer argues that autonomous reflexives tend to embark on projects whose realization will separate them from their initial context and frequently represent a socio-economic break from it. ${ }^{44}$ Claire's decision to study at Capetown was made possible financially because she gained a scholarship, so she did not have to rely totally on her parents' support. She gained the scholarship because she performed extremely well in the South African Matriculation examination, which she describes as 'lucky', perhaps indicating the way she felt about its ability to facilitate her project of studying away from home. And in moving physically so far from home Claire's project entailed a social separation as well as an economic one.

Another indication of Claire Palley's autonomous reflexivity appeared when she discovered, very quickly, that microbiology was not for her:

And then I found I was behind the rest of the class, because I'd never done advanced Mathematics at school, I'd never done Chemistry, I'd never done Physics, Zoology was a new subject and here I was doing all these subjects and the boys had done it all at school, and I was getting left behind; it was terrible ...

Claire's solution to this discovery was not to give up, or to run back home, but to deal with the situation herself: she decided to study Law instead, and went to see the Dean of the Law Faculty:

He was very nice; he knew my grandfather, and although it was five months into the first year, he allowed me to change at that stage to Law and three months later I passed the exams, which was sheer luck, because I should never have passed, because I could pass easily things like Latin and Constitutional Law, that was very easy, but I had to fill up with psychology and economics. Economics was ok, but psychology ... awful, I couldn't stand it and never used to go, I never went to the practicals, and managed just to creep through; one of the demonstrators used to sign me in although I wasn't there, and I just got a Third (the only time in my life I got a Third!). And so from then I went on with Law.

This approach to resolving a serious setback in the project upon which she had embarked, of getting a good degree, by thinking what to do then getting

43 Archer, op. cit., n. 4, p. 346.

44 id. 
on with it, along the lines of 'I got myself into this mess, now I have to get myself out of it' displays precisely the characteristics of Archer's 'autonomous reflexives'. These are people, Archer argues, who know what they want in society and formulate clear projects to achieve it. If the project is subject to 'contraction' or 'constraint', it is scrutinized subjectively and lessons are learnt. Autonomous reflexives '... both know what they want and also know a good deal about how to go about getting it. They do so strategically, as agents who endorse the life-politics of the possible. ${ }^{45}$

The second characteristic that Archer identifies in 'autonomous reflexives' is that a considerable amount of their internal conversation is about society "... about the means, the "costs" and the "benefits" of seeking to realise one's ultimate concerns within it.' Since this involves a two-way relationship between structure and agency, which can involve both 'elastication' and 'contraction' of their aspirations, autonomous reflexives tend to change over their lifetimes. In becoming detached from their original 'social moorings', the new contexts they confront present them with a different array of questions to answer. ${ }^{46}$ This is certainly true of Claire Palley, who found herself moving from South Africa to Southern Rhodesia as a direct result of marrying her husband, Ahrn Palley. She had met him at university, when they were both studying law, although he was 17 years her senior, and was a qualified doctor, working as a pediatrician. (He had always wanted to be a barrister, and so studied law as a mature student.) Ahrn Palley became an MP in Southern Rhodesia, where the Palleys moved in the late 1950 s because of their opposition to apartheid. ${ }^{47}$ In fact, as they soon found out, the political situation in Rhodesia was not much better, in terms of racial tension, than South Africa. At that time, Rhodesia had one of the largest white-settler populations in Africa, and a political system which was very similar to the apartheid regime of its close neighbour, giving little voice to the black population of more than two million people. ${ }^{48}$ Although he sat for the Democratic Party (which Claire described as 'a sort of right-wing Labour Party') for one year, in 1958-59, Ahrn Palley, being firmly opposed the unequal treatment of the black population, soon found it too right-wing, and sat as an independent MP for the predominantly black constituency of Highfield from 1962 to $1970 .^{49}$ Ian Smith, later notorious as the Prime Minister who made a unilateral declaration of independence from British rule in 1965, described Ahrn Palley as 'a one-man opposition party' and was said, despite their political differences, to hold him 'in the greatest respect'. ${ }^{50}$ Claire too did not share the outlook of the majority of her white

45 id., p. 254.

46 id., p. 213.

47 Obituary, 'Ahrn Palley' Times, 15 May 1993, 17.

48 D. Sandbrook White Heat: A History of Britain in the Swingin' Sixties (2007) 126.

49 Obituary, op. cit., n. 48.

50 id.; Sandbrook, op. cit., n. 49, p. 128. 
compatriots. She recalls visiting Rhodesia shortly before going to live there: '... we went to see it and there were white women sitting in the hotel drinking at ten o'clock in the morning ... just the sort of society which I disapproved of.'

The Palleys' radical political views meant that they were not accepted by the ex-pat community in Rhodesia:

In fact it is one of the things that made me finally decide that the future of the boys was in England. White society, because he was pro-African, boycotted us. My husband wanted the children brought up as Jews, and my youngest son went to a Jewish nursery school. When it was his fourth birthday, he invited everyone in his class, like all the other children did, and he had his twenty three invitations out but only two children came. I can remember him sitting waiting at the party, waiting, waiting (and his brother, who had a birthday the same day, but was two years older, and went to a different school, had all his classmates there) and I can remember it to this day. Eventually my son opened his two presents, and the ones that we had bought him. I will never forget that day.

The ostracism experienced by the Palleys while shocking in its cruelty to their young son, was unsurprising in the context of Southern Rhodesia. As Claire says, 'People thought that there was apartheid in South Africa, but that Southern Rhodesia was a British colony and it was fine. But it was not true in fact. There was enormous discrimination. ${ }^{51}$

The new situation in which she found herself provided Claire with much to think about. She shared her husband's anti-racist views, but was not politically active when they first arrived in Rhodesia, as she had five sons in quick succession. However, she soon began to make her own contribution to the struggle against apartheid:

I used to write articles in a magazine called the Central African Examiner, which was like the Economist for Central Africa. And also in women's magazines. So I'd write about women's rights and particularly black African women, and their lack of rights.

Claire's decision to publish these articles, focusing on gender and social inequality, reflects that aspect of her 'internal conversation' which is about society, and the means of realizing her concerns within it. She was bringing up five children, but nevertheless, finding injustice around her, wanted to do something about it, and journalism allowed her to do that.

Another feature which Archer identifies as characterizing autonomous reflexives is an unproblematic dovetailing of their concerns; their ultimate concern is work outside the home, and all other concerns (including interpersonal relations) tend to be subordinated to this concern. This does not mean such persons are inconsiderate, because they also try to elaborate what Archer calls 'an ethic of fairness', which gives other people their due, while protecting their own ultimate concern. ${ }^{52}$ And the concern with work is not

51 See, for example, B. Pimlott, Harold Wilson (1992) 451.

52 Archer, op. cit., n. 4, p. 213. 
with ambition, but with intrinsic satisfaction - autonomous reflexives seek an occupational context which meets this desire, while imposing the minimum of undesired requirements. ${ }^{53}$

The decisions that Claire Palley took about her life reflect this aspect of Archer's theory precisely. After her move to Southern Rhodesia she was bringing up her five sons while her husband worked as an MP, and was managing a household of thirteen people:

I used to joke that I was running a boarding house, because I had eventually the five children and my husband and me, which was seven and my mother-inlaw which was eight and my brother-in-law also lived with us, so that was nine and four African servants, so that was thirteen, and you had to buy food and shop and supervise; you'd be surprised how much organisation it took all the time.

However, it was not long before Claire was focusing on work outside the home as well, just as Archer would predict. She not only wrote journalism, as we have seen, but also began to act as a research assistant for her husband, providing him with the evidence he needed for the speeches he was making in parliament:

I also acted as a research assistant to my husband, and did a lot of research for him. I remember spending about three weeks on research relating to the Law and Order Maintenance Bill, which the governing party wanted to introduce so it could ban meetings, have a mandatory death penalty for offences like arson. And I worked on the Civil Authorities (Special Powers) Act and the Offences Against the State Act. And I researched that and he must have spent two or three weeks on that Bill, virtually two or three weeks during all working hours talking about Law, which was all stuff that I wrote.

In December 1959 Claire was appointed to a lectureship at the University College of Rhodesia and Nyasaland. She describes it as 'a branch of London University':

The University College of Rhodesia and Nyasaland taught London University degrees. And it had all sorts of benefits. All staff were required to do a London $\mathrm{PhD}$, and you were allowed to do it full-time, even though you were teaching. You had to register for a $\mathrm{PhD}$, but you were allowed to do it while you were teaching.

Archer argues that by accentuating 'work' as their prime concern, autonomous reflexives focus upon 'performative achievement' as that which they value most highly; but because they also have to accommodate subsidiary concerns, such as inter-personal relations, this involves elaborating an 'ethic of accommodation' to justify their ultimate concern with work in relation to their treatment of others. 'The ethic of accommodation offers a definition of "fairness" - a justified demarcation between the rights and responsibilities of the subject and the rightful expectations of others. ${ }^{54}$ This

53 id,. p. 350 .

54 id., p. 217. 
is not just a matter of convenience; Archer notes that autonomous reflexives tended to be morally very sensitive, and it is important to understand that inter-personal relations are amongst their concerns, causing them to ensure that they dovetailed this subordinate concern with their primary one of work. ${ }^{55}$ Claire's concern for her family, even when she was heavily involved in her academic work, both in terms of teaching and in researching for her $\mathrm{PhD}$, can be seen in the way she structured her life (with her husband's assistance) so as to be able to spend some 'quality time' with her children:

And he was very good towards the end of my $\mathrm{PhD}$, when I was trying to complete my PhD, doing full days lecturing. And he used to come home at five o'clock in the evening from Parliament, see that the children were bathed, see that they had their supper, then I could come and tell them a story before they went to bed. That way for 6 months he was absolutely wonderful when I was finishing my doctorate.

The next defining feature of communicative reflexives is their individualism. Archer comments: 'These are independent people, whose selfsufficiency makes them something of a "loner". 56 This is true regardless of whether they are married or in a similar intimate relationship; quintessentially they are not dependent upon others; they are philosophical individualists, with a '... profound belief that they, and everyone else, must take personal responsibility for themselves. ${ }^{57}$ The autonomous, existential quality of Claire's philosophy of life has deep roots in her upbringing:

I owe my character of being tough to my father. He said you must always stand up for the truth, you must be brave. He told the story of George Washington and the cherry tree. I don't know how many times I have heard that story! ${ }^{58}$

Claire's father had a strong influence on her belief in personal autonomy:

He joined up on the first day of World War 1, was decorated almost immediately because he rescued a wounded officer, and ended up as an officer. He was in the predecessor to the Royal Flying Corps, flying from naval vessels, and then the RFC was formed and he trained for the first bombing raids over Berlin ... My father joined up again in World War 2, and got his wings again. His attitude made me feel I must be courageous, and although I do like to be loved, I will stand up and say things even though it's painful.

Archer argues that every agent prioritizes their concerns, and crystallizes them into determinate projects. They also arrive at some orientation towards

55 id., p. 237.

56 id., p. 217.

57 id., p. 214.

58 As a little boy, George Washington damaged his father's favourite cherry tree with his new hatchet. The tree died. His father discovered the dead tree and was very angry, asking if anyone knew anything about it. George owned up, though he was very frightened. His father was not angry, but praised him for telling the truth. (This story is popular, but probably apocryphal.) 
their encounters with constraints and enablements. It is the combination of these two deliberate outcomes which constitute their 'stance' towards society. ${ }^{59}$ The importance of 'stance' is that fundamentally it represents a subjective judgment by the agent about the importance she attaches to her objective social context and its place in her life ... according to their concerns, subjects determine how much of themselves they will invest in the social order. ${ }^{60}$ Thus 'stance' means that our personal powers are crucial in mediating the importance of society to us, and in the case of autonomous reflexives, means that they will be 'accommodative' towards the social, seeing their context as a means towards the realisation of a concern. ${ }^{61}$ Adopting a stance:

... is not like holding an abstract point of view; it is rather a commitment to a distinctive course of practical action in society. It is a commitment which subjects make to themselves, within the internal conversation, and ... it is an acceptance of a particular way of being-in-the-world. ${ }^{62}$

In the case of autonomous reflexives, who invest themselves in performative concerns, this produces '... active agents, who are actively seeking a context which will prove compatible with that which they care about most. ${ }^{63}$ We can see this reflected in Claire's life when she makes the decision to leave Rhodesia. While her ultimate concern was to remain an academic, Claire also wanted to fulfil her duty to her children as well as wanting to be an activist.

Meanwhile, Ahrn and I had decided to send the children to boarding school in England. His political views were making life increasingly difficult for them ... I wanted to move to the UK so that the children had somewhere to go in the holidays, and so that I could go regularly to visit them; not only me but my husband too. I wanted to visit them in term-time, and have them with me all vacations. My husband used to quote Kipling to me and say how terrible it was that children didn't see their parents for a year or couple of years, that they needed to see their parents regularly, and it was my duty to go to the UK and establish a home for the children ... He brought the adverts from The Times home, and pointed out to me the Aberystwyth appointment and eventually the Belfast appointment ... The whole of my life was around the children - I wasn't thinking of my career, the last thing I was thinking of was my career, or that I'd get promotion when I got there. I was thinking 'I've got to do things for the children'.

Although expressed in terms of the needs of the children, it was undoubtedly the case that when she successfully gained a lectureship at Queen's University Belfast, it enabled Claire to pursue her own career as well as providing her with a family home nearer to her children. By undertaking this

59 Archer, op. cit., n. 4, p. 349.

60 id., p. 351.

61 id., p. 353.

62 id., p. 354.

63 id., p. 353. 
move, she thus achieved the 'dovetailing of concerns' which Archer identifies as a key feature of the lives of autonomous reflexives. ${ }^{64}$

There is one final characteristic that Archer notes about autonomous reflexives. They display a distinct preference for self-employment, or working as lone practitioners (in academic terms, we would refer to the 'lone scholar'):

They neither need nor welcome supervision because they are their own taskmasters and shun the conviviality of group-working as a distraction ... However, they also contribute to the development of any institution they belong to, because of their hard work and innovative contributions. Because they devote themselves single-mindedly to that which they care about most, they foster institutional growth and development ... Hence their effects are morphogenetic. $^{65}$

The morphogenetic characteristics of Claire's character can be seen early in her life when she was working at the University College of Rhodesia and Nyasaland, where she became Secretary of the AUT and campaigned for equal rights for women:

... we got equal salary and we got equal travel rights so that when you were terminated or whatever you had the travel rights, so that was a very great help when I moved; my children's fares were paid for. The university fought it like mad, but they couldn't do anything about it, there it was, it was equal, the AUT had agreed and I had the same rights as any man who moved his family ...

The morphogenetic character of Claire's professional life was also clear after she had left Belfast. Claire visited the University of Kent in 1973 to act as external assessor for a Chair appointment; while she was there she was offered a Chair herself, which she decided to accept. As she explains:

It had become increasingly difficult for the children in Belfast, and I was under some pressure from my husband to give up our house in Belfast (he said 'It's a waste, having a family home in Belfast when the children can't easily go there') so I moved to Kent.

At that time, Kent was a radical Law School, with many young scholars who were disillusioned with black-letter law and were adopting alternative sociolegal or critical approaches instead. Claire remembers:

There was a lot of fighting about what you could teach. To give you an idea of what it was like, the textbook for the first year English Legal System course was Berger and Luckman's Social Construction of Reality, which is very good, but a difficult book for first-year law students.

During the course of her first year at Kent, Claire was approached to become Master of Darwin College, a position which involved her being only parttime in the Law School. As Chair of the Law Board, Claire's task was to try and mediate between a very radical Law School, which had strong views

64 id., p. 213.

65 id., p. 359. 
about the type of legal practitioners they wished to produce, and the university's more pragmatic desire to have employable law graduates who would go on to have conventional legal careers: '... my job was to get the Law Board on board, get it on a proper footing and not throw out the baby with the bath water':

... because there was very little law in the Kent degree, the result was disproportionate numbers of Kent graduates failed the professional exams, because they hadn't had the opportunity of doing standard Tort or Land Law or Contract or Criminal Law which had been done in the other universities. So other students could really sail through the exam, but these Kent people really had a hard time, which wasn't very good for the University, as you could imagine.

Claire was first helped and then succeeded in this morphogenetic project by Brian Simpson, who was appointed to a Chair at Kent soon after she arrived. One of the things Brian, as Dean of Social Sciences, had to do at Kent, together with Claire, was to build links with the legal profession. This brought its own challenges:

Brian and I went and cultivated the local law profession. I remember going to one dinner and having artichokes, being taken to the local county hotel in Canterbury and being offered dinner by the local lawyers. It was the first time I'd had them, so it was a bit tricky! You know, you look at them on your plate and I thought to myself 'I'm not sure I know how to eat these!'

By the time she left Kent in 1984 to become Principal of St Anne's College Oxford, Claire felt that they had implemented some changes: 'Well, that was Kent, and we managed to pull it back from the edge.' In line with Archer's theory, Claire's tenure of administrative offices at Kent arguably reflected her ability to contribute to the institution to which she belonged.

While most of Claire Palley's internal conversation ties in neatly with that of an autonomous reflexive, it is important to acknowledge that her internal conversation did not develop entirely consistently during her life. In many ways, Claire's marriage did not contribute to her development as an autonomous reflexive. She notes that during her marriage, she was very much under her husband's influence (unsurprising in some ways, as he was much older and more experienced than she was, quite apart from the different social mores which then pertained). She commented:

During my marriage, I was very much influenced by my husband; for 13 years I was very much under his influence. It wasn't really until I went to Belfast and lived on my own that I had an independent life of my own. I was 35 years old before I had a bank account - when I went to Queen's and wanted to buy a house, so I needed a bank account.

Thus, while during the course of her marriage Claire continued to exhibit characteristics of an autonomous reflexive, the development of her internal conversation should be seen in the overall context of her personal life at that time. 
It is also the case that Claire showed some signs of meta-reflexivity as well. Indicative of this is her comment about the way in which her attitude to race changed around the time she went to university. She met an Indian advocate, '.. and I had never seen an educated dark person in my life. He was the most charming gentleman. It made me think again .... At university, studying economics, an African student asked a question in the middle of the lecture:

And I thought to myself 'Hmm what a cheek!' And then I thought to myself 'Ha! What a brilliant question!' And the professor saw that it was a brilliant question and he stopped what he was doing and he spent the whole of the lecture going round that question. And I remember that very well and it changed my whole attitude towards African people.

These examples of 'thinking about thinking' suggest that while Claire Palley was generally an autonomous reflexive, she also engaged in meta-reflexivity. Similarly, reflecting on her academic success, Claire noted the role her husband had played in ensuring that, despite very bad morning sickness, she still attended classes:

I did very well in my Finals, but it was because of him; he made me work. I would never have worked, I was lazy. I had a bad phenomenon - if you can do things very easily you just take it for granted that you can do it, you see, 'Look how clever I am, no hands' just like riding a bicycle with no hands. Our children do that. And I was a bit like that, until I met him.

So while autonomous reflexivity is the dominant mode of 'internal conversation' which Claire Palley engaged in, there is also evidence of some metareflexivity. And that conclusion is borne out by the comment Claire made on reading a first draft of this article. While regarding my interpretation of her as an autonomous reflexive as an accurate one, she added 'But I'm a metareflexive as well, you know'. ${ }^{66}$ While Claire's autonomous reflexivity is strongly reflected in her life story, there are also clear signs of metareflexivity.

\section{BECOMING THE FIRST FEMALE LAW PROFESSOR IN THE UNITED KINGDOM}

When Claire moved to Belfast in 1966, she did so to take up a lectureship. But she was rapidly promoted, first to a Readership in 1967 and then to a Chair in Public Law in 1970. In some respects, her rapid promotion was unsurprising; she arrived at Belfast with a $\mathrm{PhD}$ and having already gained both teaching and administrative experience in Southern Rhodesia, where she had established a law school at the University College of Rhodesia and Nyasaland. Yet, despite her previous experience, and the fact that she had published a series of articles and a book, in other ways Claire's appointment

66 Telephone interview with Claire Palley, 8 August 2014, on file with the author. 
was very surprising, since there were very few women legal academics at all at that time, and very few of them held promoted positions. ${ }^{67}$

The most comprehensive sources of information on universities and their staff at that time are the Commonwealth Universities Yearbooks. These gathered information from all Commonwealth universities annually; each edition is based on data gathered the previous academic year. In the 1970 edition (which contains data gathered in the 1969-70 academic year, the year of Claire's promotion) the Yearbook records 430 men holding full-time positions and 77 holding part-time positions in United Kingdom law schools. Women are recorded as holding 41 full-time positions and 3 part-time positions. Out of the 32 law schools recorded as offering 'full' law degrees (as opposed to service teaching for other disciplines) 10 had no female academics on the staff at all.

In the 1971 edition of the Yearbook, when Claire Palley's appointment to a Chair appears for the first time, only four other women are recorded as holding promoted positions in the United Kingdom: Olive Stone as a Reader at the LSE; Valentine Korah as a Reader at UCL, and Gabriele Ganz and Evelyn Gavin as Senior Lecturers at Southampton and Strathclyde respectively. This gives some indication of the historic importance of Claire's appointment.

At the time that Claire applied for her post, it appears that Queen's was one of the larger law schools, along with Leeds, Liverpool, and Manchester, which all had 300-350 undergraduates. ${ }^{68}$ Only Birmingham, with 450-500 undergraduates, and Oxford and Cambridge, with over 600 each, were larger. ${ }^{69}$ During the quinquennium 1968-73, Queen's underwent a period of expansion, appointing thirteen new Chairs (of which Claire was one) ${ }^{70}$ It would seem likely that a strong research profile would have been required for a law school which was looking to make its mark and maintain its position among its competitors. ${ }^{71}$

Claire had a PhD, awarded by London University in 1965 (it was unusual at that time for legal academics to hold a $\mathrm{PhD}) .{ }^{72}$ She immediately published

67 See the Commonwealth University Yearbooks for the 1960s and 70s. Discussion of the general position of female (legal) academics in the 1970s is outside the scope of this article, but see, for example, M.Tight, The Development of Higher Education in the United Kingdom since 1945 (2009) 291-3 and M. Rendel, 'Women Academics in the Seventies' in Is Higher Education Fair to Women?, eds. S. Acker and D. Piper (1984) 163.

68 J.F. Wilson and S.Marsh, 'A Second Survey of Legal Education in the United Kingdom' (1975) 13 J. of the Society of Public Teachers of Law 241, at 250.

69 id.

70 B.M. Walker and A. McCreary, Degrees of Excellence: The Story of Queen's, Belfast, 1845-1995 (1994) 138.

71 Professor William Twining, who worked at Queen's at that time recalls that: 'Queen's was a pretty strong Law School at the time.' Professor William Twining, telephone interview, on record with the author.

72 Society of Public Teachers of Law (SPTL), Directory Of Members 19715. 
this with Clarendon Press (a prestigious publisher) as The Constitutional History and Law of Southern Rhodesia 1888-1965. By 1967, when she was promoted to Reader, she had also published an article in the Modern Law Review on 'The Judicial Process: UDI and the Southern Rhodesian Judiciary' ${ }^{73}$ In the next three years she published two articles in Zambian publications on 'rethinking the judicial role' and two in the Northern Ireland Legal Quarterly on 'Constitutional Devices in Multi-Racial and MultiReligious Societies' and 'Wives, Creditors and the Matrimonial Home'. ${ }^{74}$ These were closely followed by another four pieces in 1970, the year she was promoted to a Chair. ${ }^{75}$ In addition to her academic publications, she also wrote a considerable amount of journalism. During her years in Belfast (1966-73) she authored or co-authored around ten articles in the Times on various aspects of human rights, both in Northern Ireland and in Rhodesia. ${ }^{76}$ Claire also told me that she regularly appeared on BBC radio programmes, both domestically and on the World Service during these years. Consequently, Claire was not only productive academically, she could also contribute to raising the public profile of Queen's. In addition, her expertise lay in Public Law and Claire told me that the law degree at Queen's at that time included a lot of Public Law, so she could also contribute to the teaching needs of the law school. She also taught Roman Law and Family Law, which were other areas in which the law school had teaching needs. Overall, Claire's agency, and her reflective autonomy, had put her into the position where she could be promoted to a Chair.

The system of appointment at Queen's at the time involved 'curators' who sat on the appointment panel; some of these were permanent curators, drawn from other departments and 'the great and the good', while two were 'special curators' from the department or faculty in which the post was established. If the special curators agreed on the outcome of the appointment exercise, it was very rare for the permanent curators to intervene. In Claire's case, the two special curators were Professor Lee Sheridan (then head of the law school) and Professor William Twining; since they agreed on the

73 C. Palley, 'The Judicial Process: UDI and the Southern Rhodesian Judiciary'(1967) 30 Modern Law Rev. 263.

74 C. Palley, Rethinking the Judicial Role: The Judiciary and Good Government (1969); C. Palley 'Rethinking the Judicial Role' (1968) 1 Zambia Law J.; C. Palley, 'Constitutional Devices in Multi-Racial and Multi-Religious Societies' (1968) 19 Northern Ireland Law Q. 377; C. Palley, 'Wives, Creditors and the Matrimonial Home' (1969) 20 Northern Ireland Law Q. 132.

75 C. Palley 'Law and the Unequal Society: Discriminatory Legislation in Rhodesia under the Rhodesian Front from 1963 to 1969 Part 1' (1970) 12 Race 15-47; C. Palley 'Law and the Unequal Society: Discriminatory Legislation in Rhodesia under the Rhodesian Front from 1963 to 1969 Part 2' (1970) 12 Race 139-67; C. Palley, 'Note on the Development of Legal Inequality in Rhodesia 1890-1962' (1970) 12 Race 87; C. Palley, 'Adoption Act (NI) 1967' (1970) 21 Northern Ireland Law Q. 304.

76 See the Times digital archive. 
appointment, the permanent curators did not question the decision. ${ }^{77}$ It would appear that Claire Palley possessed the overall profile which it is likely that a law school such as Queen's would have been looking for. ${ }^{78}$

When asked about making this ground-breaking appointment, Professor Twining recalls that he did not have a sense of history at the time: 'I just thought it was the right thing to do.' The Chair for which Claire applied was externally advertised, and there were both internal and external candidates who were shortlisted for the post. Professor Twining recalls that at the appointments panel, the focus, in terms of discrimination, was, in accordance with section 3 of the Irish Universities Act 1908, on the need to avoid any religious discrimination, rather than on the fact that a woman was being appointed to a Chair. He also recalls that there was at the time a concern that Queen's should not become too provincial, which to some extent favoured ex-pats like Claire, because they had teaching experience outside Northern Ireland. ${ }^{79}$ Yet there were, Professor Twining recalls, some people not on the appointments committee who questioned whether a woman could hold a Chair of Law. His recollection is that members of the committee pointed to Frances Moran in Dublin as an example of a very successful female Professor of Law. ${ }^{80}$

\section{CONCLUSION}

Analysing Claire Palley's life history through the theoretical lens of Margaret Archer allows us to provide an answer to the question with which this article began: 'Was there something about Claire Palley herself that made it likely she would become the United Kingdom's first female law professor?' Archer's theory is very helpful in focusing attention on an individual's subjectivity, and providing a framework with which it can be logically analysed. Through the exploration of the 'internal conversation' of Claire Palley, it is possible to see, at various stages in her life, those aspects of her subjectivity which contributed to her eventual appointment as a Professor of Law in Belfast in 1970. I would suggest that Claire Palley's clear tendency to autonomous reflexivity made her well-equipped to pursue a successful academic career. By itself, this does not provide a complete explanation of how it was that she became the first woman to be appointed to a Chair in Law in the United Kingdom. But it provides strong evidence that as a scholar and thinker who took her career, as well as her private life, seriously, Claire Palley was certainly the type of person one might expect to play a pioneering role in the legal academy. Her personal qualities, high-

77 Twining inteview, op. cit, n. 71.

78 See note 86 above. [please clarify - there is no $n$. 86].

79 Twining inteview, op. cit, n. 71.

80 See text relating to $n .4$ above. 
lighted by the Archerian analysis, included a strong streak of determination and resilience, supported by an independence of mind which reflected an inner strength. Thus, she was well-equipped to succeed in the male world of legal academia in which she found herself.

In evaluating the contribution of Archer's theory to a legal biography, while acknowledging its utility in terms of its focus on the personal qualities of the individual, I think it is equally important to draw attention to that which it does not do. This is not a theory (at least as it is expressed in Structure, Agency and the Internal Conversation) which encourages a holistic analysis of the context in which the individual lived. Thus, it has been said that Archer's theory involves 'too much of an internal conversation' ${ }^{81}$ It is hard not to agree with this criticism, although it is certainly not fatal to the insights which can usefully be drawn as a result of the application of her theory to new data.

Application of Archer's theory has allowed us to highlight certain aspects of Claire Palley's subjectivity, to understand how they were developed by her circumstances and the people in her life. And, most importantly, it encourages us to consider why certain individuals succeed and the conditions of that possibility. Susan Bartie has argued recently that legal scholars have much to learn from their predecessors. ${ }^{82}$ She does not limit her argument to the simplistic one that we can learn from the past, and indeed, warns against drawing '... crude connections between past lessons and future reform'. ${ }^{83}$ Bartie's more subtle argument is that studying the lives of scholarly predecessors can be 'empowering'. ${ }^{84}$ By this she means that studying the academic careers of individual scholars can reveal how academic lawyers have answered:

... the most important questions that all legal scholars must face: what and how to write and teach. In so doing, they concentrate the reader's mind on what makes a successful legal scholar and who legal scholars should seek to emulate. $^{85}$

This article is the beginning of an exploration of the biography of Claire Palley which, in due course, may lead us to consider what in her scholarly life we might wish to emulate as we contemplate the life history of the first woman professor of law in a United Kingdom university, informed by our knowledge of her 'internal conversation' and the ways in which that contributed to her success.

81 F. Vandenberghe, 'Structure, Agency and the Internal Conversation' in Revue du MAUSS Permanente (19 June 2008), at <http://www.journaldumauss.net/./?structureagency-and-the-internal>.

82 S. Bartie, 'Histories of legal scholars: the power of possibility' (2014) 34 Legal Studies 305.

83 id.

84 id., p. 317.

85 id., p. 318. 